\title{
Analisis Determinan Persistensi Laba pada Perusahaan Jasa di Bursa Efek Indonesia
}

Feni Marnilin $^{1}, \mathrm{JMV}$. Mulyadi²

1.2 Universitas Pancasila, Jl. Srengseng Sawah, Jagakarsa, Jakarta Selatan, 12640

INFO ARTIKEL

JEL Classsification:

M41

L81

Keywords:

operating cash flow, the difference between accounting profit and fiscal profit, debt level, earning persistence.

\section{$A B S T R A C T$}

This study aims to analyze and believe the factors that affect the return of sharia in the Jakarta Islamic Index. The sample of research is 29 companies with data from 2009-2015. Data analysis using multiple regression analysis. The results showed, liquidity and leverage is not significant significant to the return of sharia stocks. Operating cash flows are significant and positive against Sharia share returns. An interesting finding in this research is the role of operating cash flow as a determinant of stock returns. Future research can be proven the role of cash flow and other financial performance as a determinant of stock returns.

\begin{abstract}
A B S T R A K
Persistensi laba merupakan laba yang dapat digunakan sebagai indikator laba mendatang. Persistensi laba yang berkesinambungan dinyatakan sebagai laba yang mempunyai kualitas tinggi. Penelitian ini bertujuan untuk mengetahui analisis determinan persistensi laba pada perusahaan jasa sektor perdagangan jasa dan investasi. Sampel yang digunakan dalam penelitian menggunakan metode purposive sampling yaitu perusahaan jasa sektor perdagangan jasa dan investasi sebanyak 27 perusahaan selama tahun 2010 hingga tahun 2014. Pengujian dilakukan dengan analisis regresi berganda. Hasil penelitian ini menunjukkan bahwa aliran kas operasi dan tingkat utang berpengaruh terhadap persistensi laba, perbedaan antara laba akuntansi dengan laba fiskal tidak berpengaruh terhadap persistensi laba.
\end{abstract}

\section{Pendahuluan}

Informasi yang berkaitan dengan laba (earnings) mempunyai peran sangat penting bagi pihak-pihak yang berkepentingan terhadap suatu perusahaan. Laba yang berkualitas adalah laba yang dapat mencerminkan kelanjutan laba (sustainable earnings), dapat mempertahankan jumlah laba dimasa depan, relevan, dan reliabel (Penman, 2001). Kualitas laba dari suatu perusahaan sering dikaitkan dengan persistensi laba, karena persistensi laba merupakan komponen dari karakteristik kualitatif relevansi yaitu predictive value (Jonas dan Blanchet, 2000). Laba yang tidak terlalu berfluktuatif merupakan ciri-ciri dari laba yang persisten dan kualitas laba yang dilaporkan perusahaan adalah baik (Andi dan Ida, 2013).

Informasi mengenai laba dapat ditemukan pada laporan keuangan perusahaan. Laporan

*Email Korespondensi: ${ }^{1}$ fenimarmilin@gmail.com, ${ }^{2}$ mulyadi@univpancasila.ac.id 
keuangan perusahaan selain ditujukan untuk kepentingan pemegang saham juga ditujukan untuk kepentingan perpajakan, sehingga untuk perhitungan pajak perusahaan harus membuat laporan keuangan fiskal. Standar yang mengatur penyusunan laporan keuangan fiskal adalah peraturan perpajakan, sedangkan standar yang mengatur penyusunan laporan keuangan komersial adalah Standar Akuntansi Keuangan Dasar yang berbeda dalam penyusunan laporan keuangan tersebut dapat menimbulkan terjadinya perbedaan penghitungan laba (rugi) perusahaan. Perbedaan itulah yang menimbulkan istilah book-tax differences dalam analisis perpajakan (Resmi, 2011:369). Adanya 2 jenis laba tersebut menyebabkan laba yang dihasilkan perusahaan berbeda sehingga mempengaruhi kualitas laba. Persistensi merupakan salah satu karakteristik kualitatif relevansi laba, maka semakin besar perbedaan antara laba akuntansi dengan laba fiskal persistensi laba perusahaan akan semakin kecil. Sebaliknya semakin kecil perbedaan laba akuntansi dengan laba fiskal, maka semakin tinggi persistensi laba yang dimiliki oleh perusahaan.
Laporan arus kas merupakan salah satu laporan keuangan pokok, di samping neraca dan laporan laba rugi. Nilai yang terkandung didalam arus kas atau aliran kas pada suatu periode mencerminkan nilai laba dalam metode kas (cash basis). Data arus kas merupakan indikator keuangan yang lebih baik dibandingkan dengan akuntansi karena arus kas relatif lebih sulit untuk dimanipulasi. Arus kas dari aktivitas operasi terutama diperoleh dari aktivitas penghasil utama pendapatan perusahaan sehingga semakin tingginya aliran kas operasi terhadap laba, maka akan semakin tinggi pula kualitas laba tersebut (Barus, 2014).

Kemampuan perusahaan dalam memperoleh laba tidak dapat terlepas dari sumber modal perusahaan guna membiayai kegiatan perusahaan agar dapat terus mengembangkan usahanya dan menghasilkan laba yang maksimal. Salah satu sumber modal perusahaan adalah hutang. Tingkat hutang yang tinggi dari perusahaan akan menyebabkan perusahaan meningkatkan persistensi laba dengan tujuan untuk mempertahankan kinerja perusahaan yang baik di mata auditor dan investor (Fanani, 2010).

Tabel 1. Rata-rata Aliran Kas Operasi, Perbedaan antara Laba Akuntansi dengan Laba Fiskal, Tingkat Hutang, dan Persistensi Laba

\begin{tabular}{ccccc}
\hline Tahun & $\begin{array}{c}\text { Aliran Kas } \\
\text { Operasi }\end{array}$ & $\begin{array}{c}\text { Laba Akuntansi-Laba } \\
\text { Fiskal }\end{array}$ & $\begin{array}{c}\text { Tingkat } \\
\text { Hutang }\end{array}$ & $\begin{array}{c}\text { Persistensi } \\
\text { Laba }\end{array}$ \\
\hline 2010 & 16,29977 & -0.00359 & 0.62583 & 21,04823 \\
2011 & 14,69576 & 0.00660 & 0.68131 & 8,93978 \\
2012 & 18,54559 & 0.00938 & 0.83348 & 22,39346 \\
2013 & 18,16688 & -0.00175 & 0.87980 & 22,46680 \\
2014 & 18,29081 & 0.00409 & 0.82305 & 21,63646 \\
\hline
\end{tabular}

Sumber : Laporan Keuangan Perusahaan Jasa di BEI

Dapat dilihat pada tabel 1 kenaikan signifikan persistensi laba dari tahun 2010 sampai dengan tahun 2014 ada pada tahun 2013, yaitu sebesar 22,46680, sehingga perusahaan harus berupaya mempertahankan laba atau bahkan meningkatkan labanya. Salah satu faktor untuk menarik investor adalah dengan laba yang tidak berfluktuasi dengan demikian investor tetap akan berinvestasi pada perusahaan.

Berdasarkan latar belakang masalah penelitian ini menguji pengaruh aliran kas operasi, perbedaan laba akuntansi dan laba fiskal, dan tingkat hutang terhadap persistensi laba di perusahaan jasa sektor perdagangan jasa 
dan investasi. Penelitian ini dilakukan pada perusahaan jasa yang terdaftar di BEI. Hal ini dilakukan dengan alasan pemilihan sektor perdagangan jasa dan investasi merupakan perusahaan musiman yang memiliki laba lebih berfluktuasi dibandingkan perusahaan manufaktur dan yang lainnya sehingga dalam upaya mempertahankan laba persisten lebih sulit.

\section{Telaah Teori dan Pengembangan Hipotesis}

Teori signaling, manajemen menyajikan informasi keuangan (khususnya laba) diharapkan dapat memberikan sinyal kemakmuran kepada para pemegang saham. Laporan laba yang dapat memberikan sinyal kemakmuran adalah laba yang relatif tumbuh dan stabil (sustainable). Sustainable earnings adalah laba yang mempunyai kualitas tinggi dan sebagai indikator future earnings disebut sebagai persistensi laba (Penman dan Zhang, 2002).

Di dalam penelitian ini yang digunakan sebagai proxy dari persistensi laba adalah laba akuntansi sebelum pajak (PTBI) atau laba operasi (Asma, 2013). Laba yang digunakan adalah laba operasi. Laba operasi memiliki tingkat persistensi yang tinggi karena merupakan pendapatan yang berasal dari kegiatan utama perusahaan (Sugiri, 2003). Laba akuntansi sebelum pajak (PTBI) adalah laba atau rugi bersih yang diperoleh perusahaan sebelum dikurangi dengan beban pajak. Persistensi laba dapat ditentukan dengan rumus sebagai berikut:

$$
\text { PTBI }_{t+1}=\gamma 0+\gamma 1 \text { PTBI } t+\mathrm{U}_{\mathrm{t}+1}
$$

Ket : PTBIt+1 = Laba akuntansi sebelum pajak periode mendatang.

PTBIt = Laba akuntansi sebelum pajak periode saat ini.

Aktivitas operasi adalah aktivitas penghasil utama pendapatan perusahaan (principal revenue-producing activities) dan aktivitas lain yang bukan merupakan aktivitas investasi dan aktivitas pendanaan. Aliran kas dari aktivitas operasi terutama diperoleh dari aktivitas penghasil utama pendapatan entitas. Pada umumnya arus kas tersebut berasal dari transaksi dan peristiwa lain yang mempengaruhi penentapan laba atau rugi bersih (Syakur, 2009).

Dalam PSAK Nomor 2 paragraf 13 (IAI : 2009) menyatakan bahwa jumlah aliran kas yang berasal dari aktivitas operasi merupakan indikator yang menentukan apakah dari operasinya perusahaan dapat menghasilkan arus kas yang cukup untuk melunasi pinjaman, memelihara kemampuan operasi perusahaan, membayar deviden dan melakukan investasi baru tanpa mengandalkan pada sumber pendanaan dari luar. Informasi mengenai unsur tertentu arus kas historis bersama dengan informasi lain, berguna dalam memprediksi arus kas operasi masa depan.

\section{Perbedaan antara Laba Akuntansi dengan Laba Fiskal}

Perbedaan antara laba akuntansi dengan laba fiskal terjadi karena adanya rekonsiliasi fiskal pada akhir periode pembukuan. Perbedaan tersebut disebabkan oleh ketentuan pengakuan dan pengukuran yang berbeda antara Standar Akuntansi Keuangan dan Peraturan Pajak. Perbedaan tersebut secara umum dikelompokkan kedalam perbedaan permanen dan perbedaan temporer atau waktu (Martani dan Persada, 2009).

Perbedaan permanen disebabkan oleh pengaturan yang berbeda terkait dengan pengakuan penghasilan dan biaya antara standar akuntansi keuangan dengan ketentuan peraturan perundang-undangan perpajakan. Jadi dapat dikatakan bahwa berdasarkan ketentuan peraturan perundang-undangan perpajakan, ada beberapa penghasilan yang bukan merupakan objek pajak, sedangkan secara komersial penghasilan tersebut diakui sebagai penghasilan. Perbedaan temporer atau waktu disebabkan karena adanya perbedaan waktu pengakuan 
penghasilan dan biaya untuk penghitungan laba. Perbedaan ini terjadi karena berdasarkan ketentuan peraturan perundang-undangan perpajakan terdapat penghasilan atau biaya yang boleh dikurangkan pada periode akuntansi terdahulu atau periode akuntansi berikutnya dari periode akuntansi sekarang. Sementara itu, komersial mengakuinya sebagai penghasilan atau biaya pada periode yang bersangkutan.

Perbedaan antara laba akuntansi dengan laba fiskal menggunakan proksi beban pajak tangguhan dihitung dengan formula sebagai berikut:

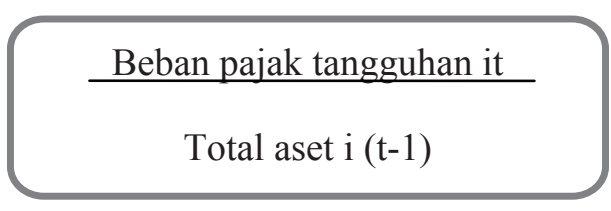

\section{Tingkat Hutang}

Tingkat hutang yang besar akan menyebabkan perusahaan meningkatkan persistensi laba dengan tujuan untuk mempertahankan kinerja perusahaan yang baik di mata auditor dan investor (Fanani, 2010). Hasil penelitian Pagalung (2006) menunjukkan bahwa adanya pengaruh positif antara tingkat hutang terhadap persistensi laba. Tingkat hutang diukur dengan proksi rasio hutang terhadap total aktiva. Rasio hutang terhadap total aktiva didapat dari membagi total hutang perusahaan dengan total aktivanya, yaitu :

Debt to Total Assets Ratio : Total Hutang

Total Aktiva

\section{Pengaruh aliran kas operasi terhadap persistensi laba}

Data arus kas merupakan indikator keuangan yang lebih baik dibandingkan dengan akuntansi karena arus kas relatif lebih sulit untuk dimanipulasi. Sehingga semakin tingginya aliran kas operasi terhadap laba maka akan semakin tinggi pula kualitas laba tersebut (Andreani dan Vera, 2014). Hasil penelitian yang dilakukan oleh Andreani dan Vera (2014) serta Asma (2013) menyatakan bahwa aliran kas operasi berpengaruh positif dan signifikan terhadap persistensi laba, hasil ini berbeda dengan penelitian Hanlon (2005) yaitu aliran kas berpengaruh negatif dan signifikan terhadap persistensi laba sedangkan pada penelitian Meythi (2006) yaitu aliran kas tidak berpengaruh signifikan terhadap persistensi laba, maka penulis akan mengembangkan hipotesis penelitian sebagai berikut :

$\mathrm{H}_{1}$ : Aliran kas operasi secara parsial berpengaruh signifikan terhadap persistensi laba.

\section{Pengaruh perbedaan antara laba akuntansi dengan laba fiskal terhadap persistensi laba.}

Adanya 2 jenis laba tersebut menyebabkan laba yang dihasilkan perusahaan ber-beda sehingga mempengaruhi kualitas laba. Persistensi merupakan salah satu karakteristik kualitatif relevansi laba. Peneliti yang melakukan penelitian perbedaan antara laba akuntansi dan laba fiskal seperti Wijayanti (2006), Wiryandari dan Yulianti (2008) serta Hanlon (2005) memperoleh hasil penelitian yang sama bahwa perbedaan antara laba akuntansi dengan laba fiskal mempunyai pengaruh negatif dan signifikan terhadap persistensi laba, maka penulis mengemukakan hipotesis sebagai berikut :

$\mathrm{H}_{2}$ : Perbedaan antara laba akuntansi dengan laba fiskal secara parsial berpengaruh signifikan terhadap persistensi laba.

\section{Pengaruh tingkat hutang terhadap persistensi laba \\ Manajemen yang memilih hutang sebagai} alternatif sumber modal dituntut untuk dapat bekerja keras agar penggunaan modal tersebut dapat memberikan keuntungan yang besar bagi perusahaan, sehingga perusahaan dapat berkembang dan mampu membayar hutang tersebut kepada kreditor. Andreani dan Vera 
(2014) menyatakan bahwa tingkat hutang tidak berpengaruh signifiikan terhadap persistensi laba, hal ini berbeda dengan penelitian Fanani (2010) yaitu tingkat hutang berpengaruh positif dan signifikan terhadap persistensi laba, sehingga penulis dapat mengemukakan hipotesis penelitian sebagai berikut :

$\mathrm{H}_{3}$ : Tingkat hutang secara parsial berpengaruh signifikan terhadap persistensi laba.

\section{Metode}

Metode penelitian yang digunakan termasuk kedalam kategori kuantitatif dengan metode korelasional, yaitu suatu metode penelitian untuk membuktikan ada atau tidaknya hubungan dan pengaruh antara dua variabel atau lebih dengan menggunakan model regresi linier berganda. Sumber data dalam penelitian ini adalah sumber data sekunder, dimana data diperoleh secara tidak langsung, artinya data-data tersebut berupa data yang telah diolah lebih lanjut dan data yang disajikan oleh pihak lain. Data yang digunakan yaitu laporan keuangan tahunan. Periode yang digunakan dari tahun 2010 sampai dengan tahun 2014. Adapun teknik penentuan data terbagi menjadi dua bagian, yaitu populasi dan sampel. Populasi yang menjadi obyek penelitian ini adalah laporan tahunan perusahaan-perusahaan jasa sektor perdagangan jasa dan investasi yang terdaftar di Bursa Efek Indonesia periode 2010 sampai 2014 yaitu sebanyak 115 perusahaan. Sedangkan sampel dalam penelitian ini sebanyak 27 perusahaan. Data dalam penelitian ini diperoleh dengan menggunakan metode dokumentasi yaitu pengumpulan data dengan cara mengumpulkan data sekunder dari laporan keuangan yang telah dipublikasikan di BEI melalui www.idx.co.id. Variabel bebas dalam penelitian ini ada tiga yaitu Aliran Kas Operasi $\left(\mathrm{X}_{1}\right)$, Perbedaan antara Laba Akuntansi dengan Laba Fiskal $\left(\mathrm{X}_{2}\right)$, dan Tingkat Hutang $\left(\mathrm{X}_{3}\right)$. Variabel dependen dalam penelitian ini adalah persistensi laba (Y). Persitensi laba dihitung dengan rumus sebagai berikut:

$$
\operatorname{PTBI}(t+1)=y 0+y 1 P T B I t+U t_{+1}
$$

Teknik analisis data mencakup uji asumsi klasik dan analisis regresi berganda. Pengujian asumsi klasik dalam penelitian ini terdiri dari Uji Normalitas menggunakan uji Kolmogorov Sminor-test, Uji Multikolinieritas menggunakan Variance Inflation Factors (VIF), Uji Heterokedastisitas menggunakan uji Rank Spearman, dan Uji Autokorelasi melalui uji Durbin-Watson (DW test). Dalam penelitian ini, analisis regresi linier berganda digunakan untuk membuktikan sejauh mana pengaruh aliran kas operasi, perbedaan laba akuntansi dan laba fiskal, dan tingkat hutang terhadap persistensi laba di perusahaan jasa sektor perdagangan jasa dan investasi yang terdaftar di BEI. Pada penelitian ini untuk uji hipotesis menggunakan uji signifikansi parsial melalui uji t dan untuk uji signifikansi simultan melalui uji f serta uji koefisien determinasi untuk melihat seberapa besar variabel independen (X) berpengaruh terhadap variabel dependen (Y) yang dinyatakan dalam persentase.

\section{Hasil Penelitian dan Pembahasan}

Hasil perhitungan nilai Kolmogorov untuk model regresi yang diperoleh sebesar 0,085 dengan probability ( $\mathrm{p}$-value) sebesar 0,08. Nilai probability uji Kolmogorov lebih besar dari tingkat kekeliruan 0,05, maka dapat disimpulkan bahwa nilai residual dari model regresi berdistribusi normal. Berdasarkan hasil pengujian multikolinearitas nilai VIF kurang dari 10. Hasil tersebut menunjukkan tidak ada korelasi yang cukup kuat antara sesama variabel bebas, dimana nilai VIF dari ketiga variabel bebas lebih kecil dari 10 dan nilai Tolerance di atas 0.10 dapat disimpulkan tidak terdapat multikolinieritas diantara ketiga variabel bebas. Hasil uji heteroskedastisitas diperoleh korelasi nilai residual dengan variabel $\mathrm{X} 1, \mathrm{X} 2$, dan $\mathrm{X} 3$ tidak signifikan yang ditunjukkan dengan nilai signifikan $(\mathrm{X} 1=0.272, \mathrm{X} 2=0.939, \mathrm{X} 3=0.734)$ lebih dari 0,05 . Sehingga disimpulkan tidak 
terjadi heterokedastisitas dalam model regresi yang diperoleh. Berdasarkan hasil pengujian autokorelasi diperoleh nilai statistik DurbinWatson $(\mathrm{D}-\mathrm{W})=2.126$. Karena nilai DurbinWatson model regressi (2.126) lebih besar dari dU (1.7645) dan kurang dari 4-dU (2.2355), yaitu daerah tidak ada autokorelasi maka dapat disimpulkan tidak terjadi autokorelasi pada model regresi.

Hasil perhitungan koefisien regresi linier berganda dengan menggunakan bantuan program SPSS dapat dirangkum pada table berikut.
Hasil koefisien regresi yang diperoleh dari tabel di atas dapat ditulis dalam bentuk persamaan yang menggambarkan hubungan data $\mathrm{X}$ dan $\mathrm{Y}$ yang digunakan adalah sebagai berikut: $\mathrm{Y}=17.510+0.168 \mathrm{X}_{1}+12.138 \mathrm{X}_{2}+$ (1.476) $\mathrm{X}_{3}$. Persamaan regresi linear berganda yang diperoleh dapat dijelaskan sebagai berikut:

a. Konstanta sebesar 17.510 persen menunjukkan nilai rata-rata persistensi laba pada Perusahaan Jasa Sektor Perdagangan Jasa dan Investasi selama periode tahun 2010-2014 tidak ada perubahan pada aliran

Tabel 2. Hasil Pengujian

\begin{tabular}{lrrrr}
\hline Keterangan & \multicolumn{1}{c}{ B } & Std. Error & \multicolumn{1}{c}{ t-hitung } & \multicolumn{1}{c}{ Sig. } \\
\hline Arus Kas Operasi & .168 & .081 & 2.068 & .041 \\
Laba Akuntansi vs Laba Fiskal & 12.138 & 27.554 & .441 & .660 \\
Tingkat Hutang & -1.476 & .515 & -2.865 & .005 \\
Constant & 17.510 & 1.301 & & \\
R-Square & .121 & & & \\
Adjusted R-Square & .101 & & & \\
F-hitung & 6.010 & & & \\
Sig. F & 0.000 & & & \\
\hline
\end{tabular}

kas operasi, perbedaan antara laba akuntansi dengan laba fiskal maupun tingkat hutang.

b. Aliran kas operasi memiliki koefisien bertanda positif sebesar 0.168 , artinya setiap peningkatan aliran kas operasi sebesar 1 kali diprediksi akan meningkatkan persistensi laba sebesar 0.168 persen dengan asumsi perbedaan antara laba akuntansi dengan laba fiskal dan tingkat hutang tidak berubah.

c. Perbedaan antara laba akuntansi dengan laba fiskal memiliki koefisien bertanda positif sebesar 12.138 , artinya setiap peningkatan perbedaan antara laba akuntansi dengan laba fiskal sebesar 1 kali diprediksi akan meningkatkan persistensi laba sebesar 12.138 persen dengan asumsi aliran kas operasi dan tingkat hutang tidak berubah.

d. Tingkat hutang memiliki koefisien bertanda negatif sebesar -1.476, artinya setiap peningkatan tingkat hutang sebesar 1 kali diprediksi akan menurunkan persistensi laba sebesar -1.476 persen dengan asumsi aliran kas operasi dan perbedaan antara laba akuntansi dengan laba fiskal tidak berubah. Tingkat signifikansi tersebut adalah sebesar $\alpha=0,05$ atau $5 \%$ dengan derajat kebebasan $(\mathrm{df}=\mathrm{n}-\mathrm{k}-1) \mathrm{df}=135-3-1=131$, dimana nilai $\mathrm{t}_{\text {tabel }}$ pengujian dua arah sebesar 1.97824. Dan Dengan bantuan software SPSS, seperti terlihat pada tabel 4.8 diperoleh nilai $t_{\text {hitung }}$ variabel aliran kas operasi sebesar 2.068. Hasil yang diperoleh dari perbandingan $t_{\text {hitung }}$ dengan $t_{\text {tabel }}$ menunjukkan $\mathrm{t}_{\text {hitung }}$ lebih besar dari $\mathrm{t}_{\text {tabel }}(2.068$ $>1.97824)$ dengan nilai signifikansi $(\mathrm{p}-$ value $)=$ 0,041 lebih kecil dari 0,05 artinya dengan tingkat kepercayaan $95 \%$ dapat disimpulkan pada tingkat $\mathrm{Ho}_{1}$ ditolak dan $\mathrm{Ha}_{1}$ diterima yang berarti aliran kas operasional secara parsial memiliki pengaruh signifikan terhadap persistensi laba.

Nilai $t_{\text {hitung }}$ variabel perbedaan laba akuntansi 
dengan laba fiskal sebesar 0.441 . Hasil yang diperoleh dari perbandingan $t_{\text {hitung }}$ dengan $t_{\text {tabel }}$ menunjukkan $\mathrm{t}_{\text {hitung }}$ lebih kecil dari $\mathrm{t}_{\text {tabel }}(0.441$ $<1.97824$ ) dengan nilai signifikansi ( $\mathrm{p}$-value) $=0,660$ lebih besar dari 0,05 dapat disimpulkan pada tingkat $\mathrm{Ho}_{2}$ diterima dan $\mathrm{Ha}_{2}$ ditolak yang berarti perbedaan antara laba akuntansi dengan laba fiskal secara parsial tidak memiliki pengaruh signifikan terhadap persistensi laba.

Nilai $t_{\text {hitung }}$ variabel tingkat hutang sebesar -2.865 . Hasil yang diperoleh dari perbandingan $\mathrm{t}_{\text {hitung }}$ dengan $\mathrm{t}_{\text {tabel }}(-2.865<-1.97824)$ dengan nilai signifikansi $(\mathrm{p}$-value $)=0,005$ lebih kecil dari 0,05 dapat disimpulkan pada tingkat $\mathrm{Ho}_{3}$ ditolak dan $\mathrm{Ha}_{3}$ diterima yang berarti tingkat hutang secara parsial memiliki pengaruh signifikan terhadap persistensi laba.

Berdasarkan tabel di atas, diketahui nilai $F_{\text {hitung }}$ untuk model regresi yang diperoleh adalah 6,010 dengan nilai signifikansi sebesar 0,001 . Sedangkan perhitungan untuk $F_{\text {tabel }}$ adalah dengan tingkat signifikansi tersebut adalah sebesar $\alpha=0,05$ atau $5 \%$ dengan derajat kebebasan $(k-1,-n-k)$ df $=3,131$. Pada tabel $\mathrm{F}$ untuk $\mathrm{df}_{1}=3, \mathrm{df}_{2}=131$, maka diperoleh nilai $F_{\text {tabel }}$ sebesar 2,67 sehingga dari hasil yang diperoleh dari perbandingan $\mathrm{F}_{\text {hitung }}$ dengan $\mathrm{F}_{\text {tabel }}$ adalah $\mathrm{F}_{\text {hitung }}>\mathrm{F}_{\text {tabel }}(6,010>2,67)$, sehingga pada tingkat kekeliruan $5 \% \mathrm{H}_{04}$ ditolak dan $\mathrm{Ha}_{4}$ diterima yang berarti ketiga variabel bebas, yaitu aliran kas operasional, perbedaan antara laba akuntansi dengan laba fiskal dan tingkat hutang secara simultan berpengaruh signifikan terhadap persistensi laba pada perusahaan jasa sektor perdagangan jasa dan investasi di BEI. Berdasarkan tabel 4.10 diperoleh Nilai Adjusted R square sebesar 0,101 atau $10,1 \%$. Hasil ini berarti bahwa ada kontribusi sebesar 10,1\% pengaruh aliran kas operasi, perbedaan antara laba akuntansi dengan laba fiskal dan tingkat hutang secara simultan terhadap persistensi laba dan sisanya yaitu $89,9 \%$ dipengaruhi oleh faktor lain yang tidak diikutsertakan dalam penelitian.

\section{Simpulan, Keterbatasan dan Implikasi Hasil penelitian}

Kesimpulan dari hasil penelitian dengan menggunakan regresi linear berganda membuktikan secara parsial bahwa variabel aliran kas operasi memiliki pengaruh signifikan terhadap persistensi laba, dan perbedaan antara laba akuntansi dengan laba fiskal tidak memiliki pengaruh terhadap persistensi laba, serta tingkat hutang memiliki pengaruh signifikan terhadap persistensi laba, sedangkan secara simultan aliran kas operasi, perbedaan antara laba akuntansi dengan laba fiskal, dan tingkat hutang mempunyai pengaruh signifikan terhadap persistensi laba pada perusahaan jasa sektor perdagangan jasa dan investasi yang terdaftar di BEI.

Penelitian ini hanya meneliti aliran kas aktivitas operasi, masih ada beberapa aktivitas lainnya seperti aliran kas aktivitas investasi dan aliran kas aktivitas pendanaan. Penelitian ini hanya pada perusahaan jasa sektor perdagangan jasa dan investasi. Sampel data yang digunakan sangat terbatas yaitu 27 perusahaan. Penelitian selanjutnya dapat menambahkan variabel lainnya. Jumlah sampel yang diambi lebih banyak dan luas dengan menambahkan jenisjenis perusahaan Go Public yang lain dengan periode pengamatan yang lebih lama serta menggunakan data-data yang literatur Pusat Referensi Pasar Modal Bursa Efek Indonesia, Indonesian Capital Market Library (ICaMEL), Indonesian Capital Market Directory (ICMD), dan situs BEI ( $\underline{w w w . i d x . c o . i d})$.

\section{Daftar Referensi}

Asma, T. N. (2013). Pengaruh Aliran Kas dan Perbedaan antara Laba Akuntansi dengan Laba Fiskal terhadap Persistensi Laba. Jurnal Akuntansi, 1(1).

Barus, A. C. (2014). Analisis Faktor-Faktor yang Mempengaruhi Persistensi Laba pada Perusahaan Manufaktur di Bursa Efek Indonesia. JWEM (Jurnal Wira Ekonomi 
Mikroskil), 4(2), 71-80.

Fanani, Z. (2010). Analisis faktor-faktor penentu persistensi laba. Jurnal Akuntansi dan Keuangan Indonesia, 7(1), 109-123.

Hanlon, M. (2005). The Persistence and Pricing of Earnings, Accruals, and Cash Flows When Firms Have Large Booktax Differences. The Accounting Review 80 (March).

Ikatan Akuntan Indonesia. (2009). Pernyataan Standar Akuntansi Keuangan. Salemba Empat. Jakarta.

Jonas, G. and J. Blanchet. (2000). Assessing Quality of Financial Reporting. Accounting Horizons.

Martani, Dwi., Persada, Aulia Eka. (2009). Analisis Faktor Yang Mempengaruhi Book Tax Gap dan Pengaruhnya Terhadap Persistensi Laba. Jurnal Akuntansi dan Keuangan Indonesia. Vol 7, No 2 . Universitas Indonesia. Jakarta.

Meythi. (2006). Pengaruh Arus Kas Operasi terhadap Harga Saham dengan Persistensi Laba Sebagai Variabel Intervening. Simposium Nasional Akuntansi 9. Padang.
Pagalung, G. (2006). Kualitas Informasi Laba:Faktor-Faktor Penentu dan Konsekuensi Ekonominya. Disertasi. Universitas Gajah Mada. Yogyakarta.

Penman, S. (2001). Financial Statement Analysis and Security Valuation. McGrawHill Irwan. New York.

Penman, S., X.J. Zhang. (2002). Accounting Conservatism, The Quality of Earnings, and Stock Return. The Accounting Review. Vol 77, No 2.

Resmi, Siti. (2011). Perpajakan Teori dan Kasus. Buku 1 Edisi 6. Salemba Empat. Jakarta.

Sugiri, Slamet. (2002). Akuntansi Pengantar 2. UPP AMP YKPN. Yogyakarta.

Suwandika, I. M. A., \& Astika, I. B. P. (2013). Pengaruh Perbedaan Laba Akuntansi, Laba Fiskal, Tingkat Hutang Pada Persistensi Laba. E-Jurnal Akuntansi, 5(1), 196-214. Syakur, Ahmad Syafi'I. (2009). Intermediate Accounting. Publisher. Jakarta.

Wijayanti, Handayani. (2006). Analisis Pengaruh Perbedaan Laba Akuntansi dan Laba Fiskal terhadap Persistensi Laba, Akrual dan Arus Kas. Simposium Nasional Akuntansi 9. Padang. 